\title{
Psychological distress and community approach to the voice of the community health agent*
}

\author{
Sofrimento psíquico e a abordagem da comunidade na voz do agente comunitário de saúde \\ Trastornos psicológicos y enfoque comunitario a la voz del agente comunitario de salud
}

Pâmela Câmpelo Paiva ${ }^{1}$, Mônica de Olivera Nunes de Torrenté ${ }^{2}$, Fátima Luna Pinheiro Landim ${ }^{3}$, July Grassiely de Oliveira Branco $^{4}$, Bruna Caroline Rodrigues Tamboril ${ }^{5}$, Ana Larisse Teles Cabral ${ }^{6}$

\footnotetext{
* Study funded by the Fundação Cearense de Apoio ao Desenvolvimento Científico e Tecnológico (FUNCAP). It is the result of a master dissertation titled 'Mental health in the voice of community health agents', presented in the Universidade de Fortaleza (UNIFOR).

${ }^{1}$ Master's Degree in Public Health, Universidade de Fortaleza - UNIFOR. Fortaleza, CE, Brazil.

${ }^{2} \mathrm{PhD}$ in Anthropology, Université de Montréal. Professor of the Public Health Institute, Universidade Federal da Bahia ISC/UFBA. Salvador, BA, Brazil.

${ }^{3} \mathrm{PhD}$ in Nursing, Universidade Federal do Ceará - UFC. Professor of the Centro Universitário Estácio do Ceará. Fortaleza, CE, Brasil.

${ }^{4} \mathrm{PhD}$ Student in Collective Health, Universidade de Fortaleza UNIFOR. Fortaleza, CE, Brazil.

5,6 Master Student in Collective Health, Universidade de Fortaleza UNIFOR. Fortaleza, CE, Brazil.
}

\begin{abstract}
The user in psychological distress needs a service that provides a targeted assistance, that welcomes when required, acting as originator care device to the user on the network of health care. This study aimed to describe how people in psychological distress are perceived by the community in the voice of the community health worker. It is a qualitative research conducted with eighteen Community Health Agents, a Primary Care Unit Health (UAP) located in BE IV, in Fortaleza, Ceará. We used a semi-structured and individual interview. Data processing was due to the content analysis. Ethical and legal aspects on the advice No. 957,595. Through the speeches of ACS, it describes how the community perceives the person in psychic suffering and how it positions itself in the face of your everyday problems, as regards the rejection, prejudice, discrimination ne loss of identity. However it is emphasized that, because of being inserted in the community, the community health worker realizes more accurate way in which this social group is the person in mental distress. The rejection of the person who became ill is seen as a fairly common reaction, accompanied by prejudice and discrimination, marginalizing her from society.
\end{abstract}

\section{DESCRIPTORS}

Mental Health; Public Health; Community Health Workers. 


\section{INTRODUCTION}

Aiming to design a proposal for Mental Health in Primary Care, a diagnosis in this context has revealed limitations regarding programmatic initiatives, and the offer of actions directed to mental health. Although the National Policy on Mental Health advocates practices focused on the territorial dimension, they are either incipient or occur with discontinuity of initiatives/actions in this sphere ${ }^{(1)}$.

Thus, there is a gap between what is recommended by public policies and what is done in practice. According to our interpretation, the concrete principles of the psychiatric reform that guide the matricial cell actions of the network (Centers for Psychosocial Care - CAPS) are in conflict with the primary care principles when the teams need to work on integrated assistance plans. This fact is attributed to the difficulties faced by the teams of both sides when dealing with more operational aspects of the matricial strategy in mental health, namely: lack of material and human resources, excessive demands, work overload, difficulty with adherence to a matricial calendar, withdrawal of expert advice, great rotation or incompleteness of health teams, among others ${ }^{(1)}$.

The operationalization of a mental health care network in the wider social space is still in the phase of implementation. On the one hand, the whole process is susceptible to the clinical domain among psychiatrists (and in the social imaginary); and on the other hand, the Family Health Strategy (FHS) is 'unfamiliar' with the universe of mental health, the required operational logic and its specific language.

The mental health support network in Brazil is not implemented homogeneously in all states/municipalities; while some locations have the resources and are advanced in procedures, others have not achieved the same success nor excellence ${ }^{(2)}$. Thus, individuals and communities can end up as 'victims' of the weaknesses and inconsistencies of the processes throughout the psychiatric reform course.

Note that scholars ${ }^{(3)}$ advocate the need to relativize the idea of community victimization, because on one hand, the state must offer what is knowingly needed, but on the other hand, there is prejudice and unwillingness to act in mental health. Truth is that 'different people' are not accepted, nor easily incorporated into the social and health care broader context. Even for families, it is not easy to live with the reality of a 'crazy' family member. It demands adaptation.

The criticism is that the state has proposed the institutionalization of people with mental disorders even before preparing professional groups and much less, before empowering the families and communities to cope with the new reality ${ }^{(3)}$.

Faced with this reality excerpt, we set out to write this essay. To this end, we got involved in a project ${ }^{(1)}$ among those existing in the city of Salvador (state of Bahia). It aims to provide a better articulation of the CAPS segment with the Family Health Strategy (FHS), i.e., the consolidation of the matricial support. The Community Health Agents (CHA) were considered as 'spokespeople of local realities', since they reside in the community where they act.
For this peculiarity, the CHA are considered those who should deal with families continuously and with greater identification/sensitivity. In cases of family members assisted in mental health, the CHA should have more chances to recognize and act in partnership with the teams, in anticipation of the most negative impacts brought by morbidity in a community context. However, in this professional segment there is the thought of 'not considering themselves able' to recognize the severity of cases and offer any adequate solution more proactively ${ }^{(1)}$.

Thus, our novelty lies in the fact of making CHAs 'talk about the suffering' experienced daily by the community, families and people with a mental disorder. The aim is to uncover the ways these segments perceive and cope with the disease in specific contexts.

The important consideration is to keep alive the debates on the need for a better articulation between the mental health and the FHS, enabling the consolidation of Primary Care as the gateway to the Mental Health Care Network (RASM).

\section{METHOD}

This is an empirical based study committed to the reality dimensions that cannot be estimated in numbers. It is the art of approaching the universe of reasons, aspirations, beliefs, values, attitudes and meanings that become evident in the reference frame in which data were collected ${ }^{(4)}$.

It was conducted with eighteen community health agents acting in seven units of the FHS within the matricial structure under the district of the Regional Secretariat IV. The semi-structured interview helped with obtaining data. After permission of the people involved, interviews were audio recorded. Notes were also taken in a field diary after observation of the CHA's routine in the community.

The data processing and analysis were conducted according to the operative proposal of Content Analysis ${ }^{(5)}$ : 1) Data organization (phase involving the classification of reports and observations from the contact with the interviews and documents selected for analysis); 2) Data classification (stage of detailed reading of each interview, recording of the first impressions and from that, building the categories of analysis); 3) Final analysis - considered important for the understanding and interpretation of speeches, it allows the classification of elements according to their similarities and differences, and subsequent grouping according to the common characteristics.

When listening to the CHAs about how the family and community perceive the person in mental suffering and how they position themselves in face of everyday problems, emerged the following categories of analysis: Abandonment and exclusion of the sick person?; Overcoming the barrier of prejudice; Losing identity.

The study respected the ethical and legal standards for research involving human beings, according to Resolution number 466/2012 of the National Health Council. Thus, the consent and option to participate or not in the study, and the possibility to withdraw at any time, were issued by signing the Informed Consent (IC) form ${ }^{(6)}$. 


\section{RESULTS AND DISCUSSION}

The subjects react in several ways when it comes to situations related to people in psychological distress, and as the CHAs are in the community, they experience and witness how people deal with it. Some reports imply attitudes of abandonment or neglect of sick people's well-being, and others show the rejection by family members and people of the community.

When relating family members and the care of sick people, there are many feelings involved: uncertainties, affection, anger, sadness, fear, rejection, denial, and escape. Next, we address these discourses.

\section{Abandonment AND EXCLUSION OF THE SICK PERSON?}

In the identified culture, a person with mental disorder within the family is a 'veiled subject', i.e., the issue is not spoken of and the most common practice is denial. Reacting to the resistance of a family to take a family member to start treatment, a CHA states: "Does not accept the drug treatment and the monitoring. Says the son is normal and there is no problem".

The revelation that there is no problem can minimize the emotional impact caused in the community. In the family's side, denial is a legitimate mechanism of coping or adaptation to the new situation presented. These changes occur without linearity with the normal course of life, causing disruption, frustrated expectations, and resulting in additional functions for each member.

The adaptation process of the family can pass by the need to not think about the problem, and that this mechanism helps to maintain the family homeostasis ${ }^{(3)}$. However, it may occur that a 'look from the outside' extracts only what the superficiality of the mechanism shows, i.e., the impression of a situation of indifference or abandonment. The CHA expressed his perception with the following: " $I$ saw it like family abandonment, you know? That, in fact, they wanted to get rid of... Didn't care, didn't help?"

The 'not caring', 'not helping', is much more a familiar resistance mechanism to the real problem and results in the need for the CHA's intervention with the patient. Hence their persistent statement that the family denies the problem.

Regarding this issue, researchers ${ }^{(7)}$ affirm that despite the reform movements, health teams are still very much influenced by the hospital-centered model. In this model, the family becomes replaceable given the system 'capacity' of electing measures and ensuring proper patient care.

It is even possible that with this bias the health team have prevented the emancipation of users suffering from mental disorders. Unconsciously, this behavior might as well reinforce the collective imaginary, leading the community to exclude these people by not accepting this space as a place where individuals at risk of mental outbreaks should be. As another CHA verbalizes:

The neighbors have even called the police because of the

noise. They thought the mother was being assaulted.

[...] There was a day when she escaped, left the room,

beat her mother and a child passing on the street.
Despite the real risk of the person in a disease episode, the accreditation of scholars is important ${ }^{(3)}$ about the fact that the family and community must get used to or pass for well defined stages. Throughout this process, the health team can help by recognizing that each individual has different reactions for understanding and accepting this transition moment. In the proposed psychiatric reform, we find ourselves in a slow passing phase in a context of which the own professionals are afraid, but also required to assimilate. However, it is important to note that the speech against adaptation should not lead the community to become merely the spokesperson for the weaknesses and insecurities of professionals.

It is neither desirable that families care alone for these patients without any kind of support, considering the whole responsibility demanded by psychiatric patients. This condition would generate overload ${ }^{(8)}$, reflecting negatively on daily activities and concerns with social network losses.

According to researchers ${ }^{(9)}$, the families of psychiatric patients will have at least two major questions for which professionals need to be prepared: If they will take care of the person indefinitely; and how will the future of their loved one be. In the end, these family members, in most cases, are the most concerned about sick people's well-being. Respect for the family means recognizing and accepting both their skills and limitations, providing information within this field and autonomy to take well-founded attitudes ${ }^{(10)}$.

\section{Overcoming THE barRIER OF PREJUdICE}

The history and future of psychiatric patients are usually marked by prejudice. Community reactions are the most diverse. Often perceived by CHAs, the stigma manifestations or discrimination are shared through reports, among which an example is: "People discriminate those with mental problems a lot. They become a nuisance within homes and many of them live cornered".

Thus, it is clear that discrimination begins within the own home, in family ties, where detention or reclusion are the most common forms of expression of this practice. In the family center, these people often have no voice, no freedom, nor are allowed to relate with the external environment. Another community health agent brings a different perception of the phenomenon:

$$
\begin{aligned}
& \text { We note some prejudice, you know? It's very relative. } \\
& \text { A few report: 'Oh, John Doe is not right in the head!' } \\
& \text { No longer give the person all that credit. Others are a } \\
& \text { bit afraid and do not give much confidence when the } \\
& \text { person has a problem. They say: 'Oh, that Jane Doe's } \\
& \text { crazy, loony, no one gives credit'. }
\end{aligned}
$$

People in mental suffering carry with themselves the weight of disability as a reality. Firstly created by the family, then by people of the external environment, the whole way of thinking about the sick person was built in the historical and cultural context. If not addressed properly, this thought results in rejection ${ }^{(11)}$.

The increased perception of CHAs about the difficulties in the relationship of the community with people in 
psychological distress, as well as their concerns with the fact seem to originate from a sense of responsibility with the demystification of madness, in order to give these people a chance to fulfill their citizenship. We highlight the following statement from a CHA:

There is still a great prejudice against people with mental disorder. Sometimes from their own family, other times from the community.

I try to demystify the issue of mental disorder within my area. We try to treat these people as naturally as possible, so they can live and work.

The CHA's statements suggest a division between these professionals; while some view mentally disabled people as incapable of performing their daily activities independently others nurture and help, even though they are aware of the existing limitations. The new care model for mental health care proposes the social inclusion of people with mental suffering, abolishing the stigmatizing model. For matters of clarification, there is the Law number 5.692/71; in article 206, paragraph I, it establishes the 'equality of conditions' as one of the principles for teaching and guarantees as a duty of the State the offering of specialized educational services, preferably in the regular school system - article $208^{(12)}$.

Since the relationship with individuals with some kind of disorder is not common in daily life, this leads to the discrimination by 'normal' individuals when they know of the reality. In relation to the suggested, if there was a natural inclusion of people in psychological distress in the community, they could be already more adapted to the community life, minimizing the strangeness by the patient. On the other hand, both in the past and in the new organization of care to people in mental suffering, family support is necessary to bring the citizen to psychosocial care services for routine monitoring, and especially in crisis episodes ${ }^{(12)}$.

Since the relationship with individuals with some kind of disorder is not common in daily life, this leads to the discrimination by 'normal' individuals when they know of the reality. In relation to the suggested, if there was a natural inclusion of people in psychological distress in the community, they could be already more adapted to the community life, minimizing the strangeness by the patient. On the other hand, both in the past and in the new organization of care to people in mental suffering, family support is necessary to bring the citizen to psychosocial care services for routine monitoring, and especially in crisis episodes ${ }^{(13)}$.

\section{LOSING IDENTITY}

When discovering the illness, the individual, the family and the community involved notice the occurrence of major changes. In face of the changes in people's routines, there are different reactions and perceptions of the individual in psychological distress. In this context, there is an identity crisis of the one suffering from the disease and of the people around who experience the disease context. The speech of Gavião is noteworthy: "it's humiliating, they already lose their name, you know? From the moment they have any mental disorder, they start to be called crazy and some nicknames'.

In face of social attacks, the subjects take on a 'new attitude' that is not theirs. The preconceived ideas label these individuals and take away their right to spontaneity, resulting in the suspension of their personal identity due to limits imposed by the disease ${ }^{(14)}$.

Culturally, a person's name becomes essential to differentiate individuals. The proper name is used before even being born, since in society it has become a symbol of the identity of every human being. In face of a mental illness, many individuals lose their names and start to be called by stigmatizing adjectives in a social context that discriminates and segregates under the conception of its prejudgments.

On this track, reintegration and rehabilitation policies should be further elaborated to be applied in the daily lives of people in psychological distress. The Law 10.216 addresses the protection and rights of individuals with a mental disorder, and redirects the care model in mental health. This law is clear in determining a treatment aimed at the permanent social rehabilitation of the sick person, postulating that this should be accomplished preferably through community mental health services. The hospitalization, whether voluntary, involuntary or compulsory, will only be recommended when the extra-hospital resources prove insufficient ${ }^{(15)}$.

The approximation between the family and people with mental disorders is one of their main needs, since throughout their treatment process the family remain present and are responsible for their integration into society, despite the major difficulties. Although there have been changes in service, to contribute with patients' social inclusion, a referral service is necessary to provide greater support, not leaving patients without assistance nor abandoned ${ }^{(16)}$.

Patients with mental disorders must be included in society to feel truly valued, with their emotional and affective sides fulfilled, in addition to participating in work and leisure. According to the author, these actions should be implemented as a whole, by maintaining a relationship among family, patients and professionals with the vision of developing a humanized health practice ${ }^{(16)}$.

Another perspective is the community's torment with the reality of neglect of people in psychological distress. There is a perception that these individuals become forgotten and marginalized by society. According to Albatroz: "There is a lot of prejudice in society, but at the same time, they want a real solution and wish that someone would care for those people". The community is not well aware of their rights, but they experience in practice the main problems, limitations and despairs, since patients become a limiting factor in the daily lives of people involved. If there were tools serving as a support to minimize the disease impacts, this would be a chance to resignify mental health in the social context, and it would facilitate the strategies to cope with the disease. 


\section{CONCLUSIONS}

As community health workers are inserted in the community, they can notice how this social group treats people in mental suffering with more accuracy.

The rejection of people who became ill was observed as a fairly common reaction together with prejudice, discrimination, and marginalization of these people from society. Individuals are no longer recognized by name and in some circumstances, lose their identity because they do not develop their normal activities anymore, and by failing to contribute, become meaningless to society. Their desires are no longer considered, and they even lose the right to exercise their citizenship. In some cases, there is family embracement and they take good care, but this is usually associated with a higher socioeconomic status of the family.

Thus, there must be organizational arrangements in the health system to reduce the work process fragmentation, emphasizing interdisciplinary care and considering users within their contexts, families and communities, so an adequate and continuous therapeutic project can be elaborated.

\section{RESUMO}

O usuário em sofrimento psíquico necessita de um serviço que proporcione uma assistência direcionada, que acolha no momento necessário, atuando como dispositivo ordenador do cuidado ao usuário na rede de atenção a saúde. Objetivou-se descrever como as pessoas em sofrimento psíquico são percebidas pela comunidade na voz do agente comunitário de saúde. Trata-se de uma pesquisa qualitativa, realizada junto a dezoito Agentes Comunitários de Saúde, de uma Unidade de Atenção Primaria a Saúde (UAPS) situada na SER IV, em Fortaleza-Ceará. Utilizou-se uma entrevista semiestruturada e individual. O processamento dos dados deu-se pela análise de conteúdo. Aspectos éticos e legais sob parecer No 957.595. Através dos discursos dos ACS, descrevemos como a comunidade percebe a pessoa em sofrimento psíquico e como está se posiciona frente às problemáticas do seu cotidiano, no que se refere a rejeição, preconceito, discriminação e perda de identidade. Contudo destaca-se que, pelo fato de estar inserido na comunidade, o agente comunitário de saúde percebe de forma mais apurada como tal grupo social trata a pessoa em sofrimento mental. A rejeição da pessoa que adoeceu é observada como uma reação bastante comum, acompanhada do preconceito e discriminação, marginalizando-a da sociedade.

\section{DESCRITORES}

Saúde Mental; Sáude Pública; Agentes Comunitários de Saúde.

\section{RESUMEN}

El usuario de la angustia psicológica necesita un servicio que proporciona una asistencia específica, que da la bienvenida cuando sea necesario, que actúa como dispositivo de cuidado de autor para el usuario en la red de atención de la salud. Este estudio tuvo como objetivo describir cómo la gente en los trastornos psicológicos son percibidos por la comunidad en la voz del trabajador de salud comunitario. Se trata de una investigación cualitativa realizada con dieciocho Agentes Comunitarios de Salud, una Atención Primaria de la Unidad de Salud (UAP), ubicado en BE IV, en Fortaleza, Ceará. Se utilizó una entrevista semiestructurada e individual. El procesamiento de datos se debió al análisis de contenido. Aspectos éticos y legales en el asesoramiento No 957.595. A través de los discursos de ACS, que describe cómo la comunidad percibe la persona en sufrimiento psíquico y cómo se posiciona frente a sus problemas cotidianos, en cuanto al rechazo, perjuicio, pérdida ne la discriminación de la identidad. Sin embargo, se hizo hincapié en que, debido a su inserción en la comunidad, el personal de salud de la comunidad se da cuenta de manera más precisa en la que este grupo social es la persona a la angustia mental. El rechazo de la persona que se enfermaron es visto como una reacción bastante común, acompañado por el prejuicio y la discriminación, la marginación de su parte de la sociedad.

\section{DESCRIPTORES}

Salud Mental; Salud pública; Agentes Comunitarios de Salud.

\section{REFERENCES}

1. Nunes M, Jucá VJ, Valentim CPB. Ações de saúde mental no Programa Saúde da Família: confluências e dissonâncias das práticas com os princípios das reformas psiquiátrica e sanitária. Cad. Saúde Pública. 2007;23(10): 2375-2384.

2. Marques ALM. Itinerários terapêuticos de sujeitos com problemáticas decorrentes do uso do álcool em um centro de atenção psicossocial. 2010. Dissertação - Universidade de São Paulo. 2010.

3. Silva JB et al. "Padecendo no paraíso": as dificuldades encontradas pelas mães no cuidado à criança com sofrimento mental. Rev. Eletr. Enf. [Internet]. 2015 jul./set.;17(3). Disponível em: http://dx.doi.org/10.5216/ree.v17i3.25632.

4. Minayo M C S, Guerriero I C Z. Reflexividade como éthos da pesquisa qualitativa. Ciência \& Saúde Coletiva, 19(4): 1103-1112, 2014.

5. Bardin L. Análise de conteúdo. Lisboa: Edições 70, 2011.

6. Brasil. Conselho Nacional de Saúde. Resolução 466/2012 de 12 de dez. de 2012.[Acesso em: 20 out. 13]. Disponível em: http://conselho.saude.gov. br/resolucoes/2012/Reso466.pdf.

7. McGuire, AB., Kukla, M., verde, A. et al. (2014). Gestão de doença e de recuperação: uma revisão da literatura. Serviços Psiquiátricos, 65 (2), 171-179.

8. Nolasco M. Sobrecarga dos familiares cuidadores em função do diagnóstico dos pacientes psiquiátricos. 2013.168 f. Dissertação [Mestrado em psicologia] - Programa de Pós-Graduação em Psicologia da Universidade Federal de São João del Rei -PPGPSI, São João del Rei, 2013.

9. Caqueo-Urízar, A., Miranda-Castillo, C., Giráldez, S., Maturana, S., Pérez, M., Tapia, F. (2014). An updated review on burden on caregivers of schizophrenia patients. Psicothema, 26(2), 235-243. 
10. Cohen C, Marcolino JAM. Relação médico-paciente. In: Segre M, Cohen C. Bioética. São Paulo: Edusp; 1995. p. 51-62.

11. Yap, MBH., Mackinnon,A.,Reavley,N. \& Jorm, A.F.(2014). The measurement properties of stigmatising atitudes towards mental disorders: results from two community surveys. International Journal of Methods in Psychiatric Research, 23 (1), 49-61.

12. Brasil. Ministério da Educação e Cultura. Política nacional de educação especial na perspectiva da educação inclusiva. Brasília: MEC, 2008. [Acesso em: 18 maio 2014] .Disponível em: <http://peei.mec.gov.br/arquivos/politica_nacional_educacao_especial.pdf〉.

13. Gonçalves AM, Sena RR. A reforma psiquiátrica no Brasil: contextualização e reflexos sobre o cuidado com o doente mental na família. Revista Latino-Americana de Enfermagem. 2001;9(2): 48-55.

14. Mussi FC, Koizumi MS, Angelo M, Lima MS. Perda da espontaneidade da ação: o desconforto de homens que sofreram infarto agudo do miocárdio. Revista da Escola de Enfermagem da USP. 2002;36(2): 115-24.

15. Brasil. Ministério da Saúde. Secretaria Executiva. Legislação em saúde mental 1990-2002/Ministério da Saúde, Secretaria Executiva. Brasília: Ministério da Saúde, 2002.

16. Brasil. Ministério da Saúde. Secretaria de Atenção à Saúde. Departamento de Ações Programáticas Estratégicas. Saúde Mental / Ministério da Saúde, Secretaria de Atenção à Saúde, Departamento de Ações Programáticas Estratégicas. - Brasília : Ministério da Saúde, 2015. 548 p. : il. (Caderno HumanizaSUS ; v. 5) 